\title{
Response of wheat yield and its components to zinc and iron application under different levels of nitrogen
}

\author{
Gheith El-Sayed * and Ola Zakaria El-Badry \\ Agronomy Department, Faculty of Agriculture, Cairo University, Egypt \\ *Corresponding author e-mail: gheith2010@yahoo.com
}

(Received: 30/04/2020; Revised: 15/05/2020; Accepted: 26/05/2020)

\begin{abstract}
To evaluate the effect of nitrogen, zinc and iron as soil application on yield and yield component of wheat, the present study was conducted at Agricultural and Experimental Research Station at Giza, Faculty of Agriculture Cairo University, Egypt during 2015/2016 and 2016/2017 seasons. The experimental design was split-plot in randomized complete block design with three replications. Results showed that positive significant effect on plant height, number of spike $/ \mathrm{m}^{2}$, spike length; number of grain per spike, grain yield per unit area in both seasons and grain protein content in one season were achieved by application of $\mathrm{N}$ and the micronutrients. Whoever, the highest significant in the above mentioned characters was obtained either by application the highest $\mathrm{N}$ levels (100kg N/fed.) or in addition to mixture of $\mathrm{Zn}$ and $\mathrm{Fe}$. The interaction between the studied factors had significant effect on plant height and grain yield in both seasons as well as on grain protein content in the second season, where the highest values of these parameters were recorded by application of $100 \mathrm{~kg} \mathrm{~N} / \mathrm{fed}$., $\mathrm{Zn}$ and $\mathrm{Fe}$ in mixture.

Keywords: Wheat yield, nitrogen, zinc and iron.
\end{abstract}

\section{INTRODUCTION}

Wheat (Triticun aestivum L.) is the most important cereal crop in the world, because it is now the important grain crop in international commerce and it is excellent storing and shipping quality make it available to people almost everywhere. In Egypt, the total production of the wheat is still far below the annual demand. This gap can be filled by increasing wheat area especially in the reclaimed lands, increasing the productivity at the plant area and decreasing the losses in production and consumption., Consequently, Increasing wheat production under Egyptian conditions is a major concern of the Agronomist.

Balanced nutrition of the plant is one of the main factors that affects the yield quality of plant. Nitrogen fertilization is an important factor in front of wheat agronomists for achieving yield targets. Several investigator found positive response of wheat to nitrogen fertilization (Anssari et al. , 2010; Wahid, 2013; Saraka et al., 2014). Another essential nutrients are $\mathrm{Zn}$ and $\mathrm{Fe} . \mathrm{Zn}$ plays a special role in synthesizing protein, RNA and DNA, chlorophyll synthesis, thylakoid synthesis and chloroplast development. Fe play an active role in several enzymatic activates of photosynthesis as well respiration (Ali et al., 2012 and
Mosoud et al., 2012). Moreover, Zn and Fe take over different roles in crop such as a formation partitioning and utilization of photosynthesis assimilates. Several investigators recorded positive response of wheat to $\mathrm{Zn}$ and Fe fertilization (Nasiri et al., 2010; Nadim et al., 2011; Habib, 2012; Inayat et al., 2014; Ghafoor et al., 2015 and Zain et al., 2015). Consequently, the present study aimed to investigated the response of wheat yield and its components to $\mathrm{Zn}$ and $\mathrm{Fe}$ application under different $\mathrm{N}$ levels.

\section{MATEREALS AND METHODS}

Grain yield and its components of wheat (Triticum aestivum L.) cv. Giza 168 as affected by soil application of $\mathrm{Zn} \mathrm{Fe}$ and $\mathrm{Zn}+\mathrm{Fe}$ under tree $\mathrm{N}$ levels, i.e. 60,80 and $100 \mathrm{~kg} \mathrm{~N} / \mathrm{fed}$. (one Fedden $=4200 \mathrm{~m}^{2}$ ) were studied. Experiments were conducted at Agricultural and Experimental Research Station at Giza, Faculty of Agriculture, Cairo University, Egypt during two successive winter seasons 2015/2016 and $2016 / 2017$. As mean of the two seasons, the soil type of the experiments was loamy in texture where the soil fertility status cleared that soil was low in $\mathrm{N}, \mathrm{Zn}$ and $\mathrm{Fe}$ (available N, $\mathrm{Zn}$ and $\mathrm{Fe}$ were 30.3 - 32.6, $10.02-10.11$ and $2.01-2.03 \mathrm{ppm}$, respectively). The experimental design was split-plot in randomized complete block 
design in three replications. Nitrogen fertilizer levels occupied the main plots and micronutrients were allocated in sub-plots.

The preceding crop was corn in both seasons. Grains were sown on the third week of November in both seasons. Nitrogen fertilizer in the form of urea $46 \% \mathrm{~N}$ was added in a split application, one half was applied at sowing time and the rest before the first irrigation (21 days after planting). $\mathrm{Zn}$ and $\mathrm{Fe}$ in sulfate form at the rate of $20 \mathrm{~kg} / \mathrm{fed}$. were added to the soil before the first irrigation. $\mathrm{Zn}$ and $\mathrm{Fe}$ were added either individually or in mixture. At harvest time, wheat plants were collected from each sub-plot and plant height, number of spike $/ \mathrm{m}^{2}$, spike length, number of grains/spike, 1000grain weight, grain yield per unit area and grain protein content were estimated. All the data collected during the both seasons were subjected to statistical software package MSTAT-C (Michigan Stat University,1190). Least Significant Differences Test ( L. S. D.) at 0.05 probability was used to test significances among mean values of each treatment (Steel and Torrie, 1997).

\section{RESULS AND DISSCTIONS}

\section{Effect of nitrogen fertilizer levels}

Increasing $\mathrm{N}$ levels up to $100 \mathrm{~kg} \mathrm{~N} / \mathrm{fed}$. caused a significant and gradually increase in plant height, number of spikes $/ \mathrm{m}^{2}$, spike length, number of grain /spike and grain yield/fed. in both seasons and grain protein content in the second one (Table 1 and 2). As an average of two season, increasing $\mathrm{N}$ levels up to 100 $\mathrm{kg} \mathrm{N} / \mathrm{fed}$. caused an obvious increase in the above mentioned characters by $1.3,4.4,8.1,7.1,24.6$ and 9.1 $\%$ over the application of the lower nitrogen levels (60 and $80 \mathrm{~kg} \mathrm{~N} /$ fed.). Moreover, grain yield response per $\mathrm{kg}$ of $\mathrm{N}$ was calculated as 15 and $20 \mathrm{~kg}$ of grains for 80 and $100 \mathrm{~kg} \mathrm{~N} / \mathrm{fed}$., respectively. These results expected that nitrogen is one of the most important component of cytoplasm, nucleic acid and chlorophyll. Therefore, as the level of nitrogen increased rapid multiplication of cells occurs which in turn enhanced the amount of metabolist necessary for building plant organs. These results are in harmony with these recording by Anssari et al.(2010), Gheith et al. (2013), Guo et al. (2013), Wahid (2013) and Szmigiel et al. (2014) who reported that grain yield per unit area was increased significantly with increasing N levels. Moreover, Sarka et al. (2014) found that protein content in grains increased significantly was increased $\mathrm{N}$ levels.

\section{Effect of $\mathrm{Zn}$ and $\mathrm{Fe}$ fertilizer}

Results presented in Table ( $3 \& 4$ ) showed that plant height (in first season), number of spikes $/ \mathrm{m}^{2}$ and grain yield /fed. in both seasons were significantly affected by application of $\mathrm{Zn}$ and Fe. On the contrary, this effect was not true regarding spike length, number of grains /spike, grain weight/spike, thousand grain weight and grain protein content in both seasons. In general, application of $\mathrm{Zn}+\mathrm{Fe}$ combination treatment produced the highest values for the studied characters, while the lowest values were recording with application of $\mathrm{Fe}$ alone in both seasons. The previous finding may be dye to that $\mathrm{Zn}$ and $\mathrm{Fe}$, in general, are required to a healthy growth and life cycle completion (Ali et al., 2012).

Table 1: Yield and its components as affected by nitrogen levels in 2014/2015 season.

\begin{tabular}{|lccccc|}
\hline $\begin{array}{l}\text { Yield and its } \\
\text { components }\end{array}$ & $\mathbf{6 0}$ & $\mathbf{8 0}$ & $\mathbf{1 0 0}$ & $\mathbf{F}$ & L.S.D. \\
\hline $\begin{array}{l}\text { Plant height } \\
\text { (cm) }\end{array}$ & 110.3 & 110.9 & 112.6 & $*$ & 1.5 \\
$\begin{array}{l}\text { Number of } \\
\text { spikes/m }\end{array}$ & 440.6 & 445.3 & 468.2 & $*$ & 14.3 \\
$\begin{array}{l}\text { Spike length } \\
\text { (cm) }\end{array}$ & 10.1 & 10.3 & 10.8 & $*$ & 0.2 \\
$\begin{array}{l}\text { Number of } \\
\text { grains/spike }\end{array}$ & 51.7 & 53.9 & 56.3 & $*$ & 2.2 \\
$\begin{array}{l}\text { Weight of } \\
\text { grains/spike(g) }\end{array}$ & 2.5 & 2.6 & 2.8 & ns & - \\
$\begin{array}{l}\text { 1000-grain } \\
\text { weight (g) }\end{array}$ & 42.6 & 42.9 & 43.3 & ns & - \\
$\begin{array}{l}\text { Grain yield } \\
\text { (t/fed.) }\end{array}$ & 2.7 & 3.0 & 3.4 & $*$ & 0.2 \\
$\begin{array}{l}\text { Grain protein } \\
\text { content (\%) }\end{array}$ & 14.2 & 14.3 & 14.5 & ns & - \\
\hline
\end{tabular}

$*=$ Significant and ns = Not significant at 0.05 level.

Table 2: Yield and its components as affected by nitrogen levels in 2015/2016 season.

\begin{tabular}{|lccccc|}
\hline $\begin{array}{l}\text { Yield and its } \\
\text { components }\end{array}$ & $\mathbf{6 0}$ & $\mathbf{8 0}$ & $\mathbf{1 0 0}$ & $\mathbf{F}$ & L.S.D. \\
\hline $\begin{array}{l}\text { Plant height } \\
(\mathrm{cm})\end{array}$ & 114.2 & 114.5 & 114.8 & $*$ & 1.2 \\
$\begin{array}{l}\text { Number of } \\
\text { spikes/m }\end{array}$ & 439.3 & 440.1 & 441.8 & $*$ & 0.4 \\
$\begin{array}{l}\text { Spike length } \\
\text { (cm) }\end{array}$ & 9.8 & 10.3 & 10.7 & $*$ & 0.3 \\
$\begin{array}{l}\text { Number of } \\
\text { grains/spike }\end{array}$ & 57.5 & 60.5 & 60.8 & $*$ & 3.0 \\
$\begin{array}{l}\text { Weight of } \\
\text { grains/spike(g) }\end{array}$ & 2.4 & 2.5 & 2.6 & $\mathrm{~ns}$ & - \\
$\begin{array}{l}\text { 1000-grain } \\
\text { weight (g) }\end{array}$ & 42.7 & 42.8 & 44.1 & $\mathrm{~ns}$ & - \\
$\begin{array}{l}\text { Grain yield } \\
\text { (t/fed.) }\end{array}$ & 3.0 & 3.3 & 3.7 & $*$ & 0.3 \\
$\begin{array}{l}\text { Grain protein } \\
\text { content (\%) }\end{array}$ & 12.1 & 14.5 & 14.2 & $*$ & 0.4 \\
\hline * Significant and & & & & & \\
\hline
\end{tabular}

$*$ = Significant and ns = Not significant at 0.05 level.

Its plays a role in many function in plant growth and development. This function includes chlorophyll synthesis, enzymatic activities of photosynthesis, synthesizing protein, RNA and DNA (Ali et al. 2012 and Mosoud et al.,2012). The present results are in harmony with those obtained by many researchers of them Nasiri et al. (2010), Yassen et al. (2010), Nadim et al. (2011), Bameri et al. (2012), Habib et al. (2012), Khan et al. (2012), Inayat et al. (2014), Ghafoor et al. (2015) and Zain et al. (2015) who reported that 
application of micronutrient to wheat caused an increase in either grain yield or yield components.

\section{Effect of the interaction}

Results in Table (5) indicated that the interaction between the two studied factors had significant effect on plant height and grain yield pre unit area in both seasons and grain protein content in the second season. The tallest plants (114.6 and $115.5 \mathrm{~cm}$ ) and maximum grain yield (3.9 and $3.6 \mathrm{t} / \mathrm{fed}$.) in both seasons, respectively recorded by application of the highest $\mathrm{N}$ level (100 kg N/fed.) and mixture of $\mathrm{Zn}+\mathrm{Fe}$ treatment. As regarding the grain protein content, the highest value $(14.6 \%)$ was produced under the same treatment in the second season.

The results of this study showed that under the condition of this experiment, there was positive significant effect on grain yield and its related characters were achieved by application of $100 \mathrm{~kg}$ $\mathrm{N} /$ fed. and mixture of $\mathrm{Zn}+\mathrm{Fe}$. It is evident also application of $100 \mathrm{~kg} \mathrm{~N} / \mathrm{fed}$. with mixture of $\mathrm{Zn}+\mathrm{Fe}$ was the best treatment recorded the highest values of all studied character comparing with other treatments.

Table 3: Yield and its components as affected by different micronutrients in 2014/2015 season.

\begin{tabular}{|c|c|c|c|c|c|}
\hline \multirow{2}{*}{$\begin{array}{l}\text { Yield and its } \\
\text { components }\end{array}$} & \multicolumn{5}{|c|}{ Micronutrients } \\
\hline & $\mathbf{Z n}$ & $\mathbf{F e}$ & $\begin{array}{l}\mathrm{Zn}+ \\
\mathbf{F e}\end{array}$ & $\mathbf{F}$ & $\begin{array}{c}\text { L.S. } \\
\text { D. }\end{array}$ \\
\hline Plant height $(\mathrm{cm})$ & $\begin{array}{l}112 . \\
9\end{array}$ & $\begin{array}{l}106 . \\
9\end{array}$ & 114.5 & $*$ & 2.1 \\
\hline $\begin{array}{l}\text { Number of } \\
\text { spikes } / \mathrm{m}^{2}\end{array}$ & $\begin{array}{l}448 . \\
3\end{array}$ & $\begin{array}{l}440 . \\
2\end{array}$ & 458.3 & $*$ & 7.9 \\
\hline $\begin{array}{l}\text { Spike length } \\
(\mathrm{cm})\end{array}$ & 10.3 & 10.1 & 10.5 & ns & - \\
\hline $\begin{array}{l}\text { Number of } \\
\text { grains/spike }\end{array}$ & 50.6 & 51.2 & 52.3 & ns & - \\
\hline $\begin{array}{l}\text { Weight of } \\
\text { grains/spike(g) }\end{array}$ & 1.9 & 2.2 & 2.3 & ns & - \\
\hline $\begin{array}{l}\text { 1000-grain } \\
\text { weight }(\mathrm{g})\end{array}$ & 43.7 & 43.2 & 44.5 & ns & - \\
\hline $\begin{array}{l}\text { Grain yield } \\
\text { (t/fed.) }\end{array}$ & 2.4 & 2.2 & 2.6 & $*$ & 0.2 \\
\hline $\begin{array}{l}\text { Grain protein } \\
\text { content }(\%)\end{array}$ & 14.0 & 14.1 & 14.3 & ns & - \\
\hline
\end{tabular}

Table 4: Yield and its components as affected by different micronutrients in 2015/2016 season.

\begin{tabular}{|c|c|c|c|c|c|}
\hline \multirow{2}{*}{ Yield and its components } & \multicolumn{3}{|c|}{ Micronutrients } & \multicolumn{2}{|l|}{ 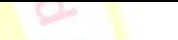 } \\
\hline & $\mathbf{Z n}$ & $\mathbf{F e}$ & $\begin{array}{l}\mathrm{Zn}+ \\
\mathrm{Fe}\end{array}$ & $\mathbf{F}$ & _.S.D. \\
\hline Plant height $(\mathrm{cm})$ & 114.5 & 114.2 & 114.7 & ns & - \\
\hline Number of spikes $/ \mathrm{m}^{2}$ & 444.0 & 450.1 & 453.2 & & 2.8 \\
\hline Spike length $(\mathrm{cm})$ & 10.1 & 10.3 & 10.4 & ns & - \\
\hline Number of grains/spike & 49.5 & 50.3 & 51.6 & ns & - \\
\hline Weight of grains/spike $(\mathrm{g})$ & 2.2 & 2.4 & 2.5 & ns & - \\
\hline 1000-grain weight $(\mathrm{g})$ & 41.2 & 41.6 & 42.5 & ns & - \\
\hline Grain yield (t/fed.) & 3.3 & 3.2 & 3.6 & * & 0.3 \\
\hline Grain protein content $(\%)$ & 12.8 & 12.3 & 13.5 & ns & - \\
\hline
\end{tabular}

Table 5: Effect of interaction on plant height $(\mathrm{cm})$, grain yield (t/fed.) and grain protein content $(\%)$.

\begin{tabular}{|c|c|c|c|c|c|c|}
\hline \multirow{2}{*}{$\begin{array}{l}\text { N levels } \\
\text { (kg/fed.) }\end{array}$} & \multirow{2}{*}{$\begin{array}{c}\text { Micro- } \\
\text { nutrients }\end{array}$} & \multicolumn{2}{|c|}{ Plant height } & \multicolumn{2}{|c|}{ Grain yield } & \multirow{2}{*}{$\begin{array}{c}\text { Grain protein } \\
2^{\text {nd }} \text { season }\end{array}$} \\
\hline & & $1^{\text {st }}$ season & $2^{\text {nd }}$ season & $1^{\text {st }}$ season & $2^{\text {nd }}$ season & \\
\hline \multirow{3}{*}{60} & $\mathrm{Zn}$ & 113.9 & 114.5 & 3.0 & 3.1 & 11.5 \\
\hline & $\mathrm{Fe}$ & 102.6 & 113.9 & 2.8 & 3.0 & 12.1 \\
\hline & $\mathrm{Zn}+\mathrm{Fe}$ & 114.5 & 114.3 & 3.3 & 3.1 & 12.7 \\
\hline \multirow{3}{*}{80} & $\mathrm{Zn}$ & 112.4 & 114.5 & 3.3 & 3.2 & 13.0 \\
\hline & $\mathrm{Fe}$ & 109.5 & 114.3 & 3.2 & 3.1 & 12.3 \\
\hline & $\mathrm{Zn}+\mathrm{Fe}$ & 114.5 & 114.8 & 3.5 & 3.4 & 13.2 \\
\hline \multirow{3}{*}{100} & $\mathrm{Zn}$ & 112.8 & 114.6 & 3.5 & 3.5 & 14.0 \\
\hline & $\mathrm{Fe}$ & 108.3 & 114.2 & 3.4 & 3.1 & 12.6 \\
\hline & $\mathrm{Zn}+\mathrm{Fe}$ & 114.6 & 115.5 & 3.9 & 3.6 & 14.6 \\
\hline \multicolumn{2}{|c|}{ F- test } & $*$ & $*$ & $*$ & $*$ & $*$ \\
\hline \multicolumn{2}{|c|}{ L.S.D. $0.05 \%$} & 2.5 & 0.5 & 0.4 & 0.3 & 1.5 \\
\hline
\end{tabular}

\footnotetext{
$*$ = Significant at 0.05 level
} 


\section{REFERENCES}

Ali, E. A. 2012.Effect of iron nutrient sprayed on foliage at differed physiological growth stages on yield and quality of some durum wheat (Triticum durum L.) varieties in sandy soil. Asian Journal. Crop Science, 4(4): 139-149.

Anssari, M.; Cheema, N. M. and Leitch, M. H. 2010. Effect of agronomic practices on the development of septoria leaf blotch and ITS subsequent effect on growth and yield components of wheat. Pak. J. Bot., 43(3):21252138.

Bameri, M.; Abdolshafi, R; Mohammadi- Nejad, Gh.; Yoysafi, Kh. and Tabatabacie, S. M. 2012. Effect of different micronutrients treatment on wheat ( Triticum aestivum L.) growth and yield. International Research Journal of Applied and Basic Sciences, 1: 219-223.

Ghafoor, A. M. R.; Soz, M. S. and Banaz, R. R. 2015. Effect of iron application to calcareous soil on growth and yield of wheat in Solaimani governorate. Kurdistan-Iraq. American Eurasian J. Agric. \& Environ. Sci., 15 (18): 1552-1555.

Gheith, E.M S; Ola Z. El-Badry and Wahid, S.A. 2013. Sowing dates and nitrogen fertilizer levels effect on grain yield and its components of different wheat genotypes. Res. J. Agric. and Biol. Sci., 9(5):176-181.

Guo, Jun-xieng; CHEnEr-ying; YIN Yang-ping; LIYong; CHEN. Xiao-quong; WLL Guang-lei and Wang Zhen-lin 2013. Nitric oxide content in wheat leaves and its relation to programmed cell death of main stem and tillers under different nitrogen levels. J. Integrative Agric., 12(2):239250.

Inayat, U. R.; Aftap,A.; Zafar, I. and Shafiult, M. 2014. Foliar application of plant mineral nutrients on wheat. A review. Journal of Agriculture and Allid. 3(2): 19 -22.

Khan, B. M.; Farooq, M.; Hussain, M. and Shahnawaz, M. 2012. Foliar application of micronutrients improve the wheat yield and net economic return. Int. J. Agric. Biol., 12: 953-956.

Michigan State University (1990): 4 series guide to MSTAT-C. Michigan.
Mosoud,B.; Rooholla, A.; Ghose, M.; Khatoon, Y. and Sated, M. T. 2012. Effect of different micronutrients treatment on wheat ( Triticum aestivum L.) growth and yield. Inll Res. J. Appl. Basic. Sci., 3(1): 219-223.

Habib, M. 2012. Effect of supplementary nutrition with $\mathrm{Fe}, \mathrm{Zn}$ chelae and urea on wheat quality and quantity. African Journal of Biotechnology, 11 (1): 2661-2665.

Nadim, M. A.; Awan, I. U.; Baloch. M. S.; Khan, E. A.; Noveed, K. and Khan, M. A. 2012. Response of wheat (Triticum aestivum L.) to deferent micronutrients and the application methods. Joutnal of Animals and Plant Sciences,22 (1): 113-119.

Nasiri, Y.; Zehtab-Salnasi; Masrullah Zadek, S.; Najafi, N. and Ghassemi, K. G. 2010. Effect of foliar application of micronutriens $(\mathrm{Fe}$ and $\mathrm{Zn}$ ) on flower yield and essential oil of chamomite (Matricaria chamomilla L.). Journal of Medicinal Plants Research, 17: 1733-1737.

Sarka, S.; Cerny, J.; Mityra, K.; Lipinska, K.J.; Kovarik, J. and Balik, J. 2014. The influence of nitrogen fertilizer on quality of winter wheat grain. MENDEL NET, 5(7):105-109.

Steel, R.C. and Torrie, S. H. 1997. In " Principles and procedures of statistics". McGrauc Hill Book company, Inc., New York, London.

Szmigiel, A.; Olehy, A. and Kolodziejczyk, M. 2014. Effect of nitrogen fertilization on quality and quantity in spring wheat. Electronic j. Polish Agric. Univ., 17(2):110-118.

Wahid, S.A. 2013. Response of some wheat genotypes to environmental condition. (M. Sc. Thesis) Fac. Agric. Univ., Egypt.

Yassen,A.; Abou El-Nour and Shedeed, S. 2010. Response of wheat to foliar spray with urea and micronutrients. Journal of American Science, 6 (9): 14-22.

Zain, M.; Khan, I.; Qadir, R. W.; Ashraf, M.; Hussain, S.; Minhas, S.; Siddique, A.; Jahngir, M. M. and Bashir, M. 2015. Foliar application of micronutrients enhances wheat growth yield and related attributes. Journal of Plant Sciences, 6 :864 - 869 . 